\title{
10
}

\section{Sawyer's Story: Guidance and Control of Adolescents in a Remote Aboriginal Community}

Victoria Burbank

\section{Introduction: Change and Continuity at Numbulwar}

Remote Aboriginal communities in Australia have not been exempt from the rapid and radical changes that have characterised recent human history (e.g. Rowse 2017). While much of this change has resulted in improved health and wellbeing for many world populations, for others the consequences have been mixed. Drawing primarily on autobiographical material from a senior Numburindi man, this chapter looks at the effect that one of these changes has brought for Aboriginal youth over a span of 30 years in the south-east Arnhem Land community of Numbulwar. Somewhat ironically, it is the continuity of these changes-the control over Aboriginal people by an outside polity - that disables what may be a necessary and helpful control over young people. How and why some individuals respond more constructively to their current circumstances than others are questions that point to the complexity inherent in the control and guidance of youth in the intercultural spaces of remote Aboriginal Australia. 
The south-east Arnhem Land community of Numbulwar was originally established by the Anglican Church Missionary Society (CMS) as the Rose River Mission. Its first Aboriginal residents were Wubuy-speaking people, known as the Nunggubuyu, or Numburindi, many of whom had previously lived at CMS missions on the Roper River and at Groote Eylandt. I have visited this community, located at the confluence of the Rose River and the Gulf of Carpentaria, on a number of occasions, first in 1977 and most recently in 2007. ${ }^{1}$ Between these years, Numbulwar grew from a community of roughly 400 to 800 relatively permanent residents. In the early mission years, Aboriginal people were 'Wards of the State' and their activities were largely under mission control. At this time, a great many changes to their lives and livelihoods were made, changes that continued throughout the years. While the people of Numbulwar were still hunting, fishing and gathering in 2007, provisions of Westerntype foodstuff, once as mission rations, later to be purchased in the 'shop', provided a major part of the diet. Marriage-related practices such as mother-in-law bestowal, ${ }^{2}$ polygyny and a pre-menarcheal marriage age for females had all but disappeared. Senior men could no longer punish, as they once did, those who violated the 'Law' - that is, the imperatives of life established in the Dreaming, which had been challenged, if not supplanted, by Christianity and other Western beliefs. Wubuy and other languages of Numbulwar's population, such as Wandarang and Anindilaguwa, had largely been replaced with Roper/Ngukurr Kriol and, for a number of residents, Aboriginal English. Most people were supported by some form of welfare and, increasingly, Western material objects had made their way into the community. Although surrounded by Western things, social arrangements and institutions, such as vehicles,

1 Beginning in 1977, I have visited Numbulwar on a number of occasions to conduct anthropological fieldwork: $1977-78$ for 18 months, 1981 for 9 months, 1988 for 7 months, 1997 for 5 weeks and between 2003 and 2007 for an approximate total of 7 months. All these projects have been undertaken with the knowledge of my research intentions and permission of the community. Informed consent has always been sought from the individuals with whom I have worked. Some of the publications from this research include: Aboriginal Adolescence: Maidenhood in an Australian Community (New Brunswick: Rutgers University Press, 1988); Fighting Women: Anger and Aggression in Aboriginal Australia (Berkley: University of California Press, 1994); and An Ethnography of Stress: The Social Determinants of Health in Aboriginal Australia (New York: Palgrave Macmillan, 2011). My last trip for the purpose of research took place in 2007. I was able to make a brief personal visit to Numbulwar in 2019. Permission for this last trip was granted by the Northern Land Council (NLC), as were all my previous visits. The NLC required one community member's support of my application to visit.

2 Once the Nunggubuyu/Numburindi and other language groups in Arnhem Land (e.g. see Shapiro 1981) bestowed little girls, perhaps around the age of four or five, upon a man as his mother-in-law. He would then, ideally, receive all of her daughters as wives should she give birth to girls (Burbank 1988, $51-52)$. 
houses, a school, governing councils, town clerks and Western schedules, the people of Numbulwar identified themselves in terms of Aboriginal categories and continued to attend to some of their older laws and customs. For at least some, this would include mother-in-law/son-in-law avoidance, the custom of mirriri that prescribes distance and respectful behaviours between mature brothers and sisters, the use of an Arandatype system of kin classification, circumcision of boys and attendance at various Indigenous ceremonies (see also Biernoff 1979; Cole 1982; Heath 1980).

While many discussions of the difficulties faced by Aboriginal people focus, appropriately, I think, on changes that have taken place in their lives, I want to frame this discussion, inspired and illustrated by segments of one man's autobiography, in terms of what I have mentioned as a significant continuity - the control over Aboriginal people by an external power. This control changed in some details, from the assimilation polices of the mission period through the integration, self-determination and intervention policies of the Commonwealth and Territory entities that have been in power over the years (Rowley 1977; Austin-Broos 2011). In effect, however, or so I argue, Aboriginal lives have been governed to a large extent by the policies and institutions of an encompassing polity that is largely ignorant of, and, usually, indifferent to, Aboriginal values and goals. As the circumstances created by this continuity have affected every part of Aboriginal being, it is no surprise that they have affected the experience of Aboriginal youth, and have long done so. I focus on just one aspect of this experience, the intergenerational guidance and control of adolescents.

\section{Adolescents: An ‘Old Man's’ Perspective}

In discussing this topic, I am guided by the words of a man in his early 50 s whom I call, pseudonymously, Sawyer. Most of my work at Numbulwar has been with women and girls but, as an older woman, over the course of three of my most recent field trips, I was able to have a series of extended conversation with Sawyer. During one of our conversations in 2003, I asked him if he could tell me what he saw as the difference in his life when he was a 'young boy' and the lives of young boys at the time we 
were speaking. Young boys, as the reader may know, is a phrase that has been used to refer to male adolescents at Numbulwar, if not elsewhere in Aboriginal Australia. Sawyer replied to my request as follows:

There is a lot of difference, not just one difference ... I tell you about my time when I was a young boy. My time when I was a young boy had simple things that I could do with my life. And those things that I wanted to do, I was really scared in doing sometimes because when I did it I was in big trouble ... Like most of the things that's wrong, like stealing ... I got into trouble for that. I wasn't stealing, I just picked it up like other boys did and I got in trouble, like sugar cane, I never ate in my life. I broke a little bit to taste but I got a hiding for that. I guess I had a strict family, living with strict family mob, they never tolerated anything that I did that was wrong.

Old way, you can't ever go talk to woman in our society; that is wrong. Can't even go an' take a woman away from home, and even take out on a walk or talk to her, that's wrong in my society. And sniffing petrol, I never sniffed but I watched boys that sniffed. The punishment [for petrol sniffing] had to be in public, that's how elders mob wanted it to happen if elder said, 'He did the wrong thing'. [Missionary] used to warn if [he] does it again [he'll] have to be banned from community. It was really strict in those days. Young men used to sleep long way from married couples, maybe a couple of kilometres away, not allowed to look at women. They would stay completely a long way from them.

There are reasons why our young kids have gone on their own path. They broke away from our culture, they can do anything, that makes me wonder why they doing that. They can go and sniff petrol anytime they want, to smoke ganja [cannabis] anytime they want to. If they feel like smoking ganja we can't stop them; they can drink alcohol anytime they want. They can play music of the tape recorder, big stereo they can buy from the shop. They can play music loud as they like it anytime. They don't worry about the next door neighbour. They can choose whatever woman they want to meet during the day or the night. And all these things that young people does that I see them do, it's completely out of my reach. I can't hold them up and say to them, 'You should be doing that'. Us mob today, we don't have any power to do anything. Our power system was lost as soon as we lost the elders to control the community. (Sawyer, 12 November 2003) 
At Numbulwar, the people adults might regard as adolescents do not fit neatly into Western categories and definitions. Their transitional life stages, for example, may be shorter than Western ones or extend beyond the teenage years. Whatever her chronological age, when a girl's breasts begin to develop she is regarded as a ngarlanyjinyung, a 'young girl', until she is married and has children. In past times, at least, the passage of an adolescent girl into marriage and motherhood might be a short one, while that of an adolescent boy's passage into manhood appears to have been more protracted. His time as a wulmurinyung, or 'young boy', begins when his body shape, voice and facial hair begin to resemble that of an adult male. As is the case with adolescent girls, he only becomes a man with marriage and children. In the past, this occurred in a male's late 20 s or early 30s. Recently, however, this prolonged period of adolescence changed and boys in their teens might be married, in spite of adult disapproval. One older woman expressed this most emphatically with her scorn of a 23-year-old's marriage. He was, as far as she was concerned, still a 'young boy' (Burbank 1988, 4, 31).

The behaviour of young people appears to have changed as well; most critically, as Sawyer indicates, some, though not all, youth seem inclined to engage in acts that both concern adults and disrupt the community on a regular basis. For example, in the late 1970s, I heard the following:

Sarah, sister's son Bentley [age 21] broke into the shop last night and took Sarah's son, Llewellyn [age 14] with him. Llewellyn took some cigarettes and two singlets but later returned them. When Sarah found out about this she began hitting Bentley on his back, yelling that he shouldn't teach her son to steal. Seeing her son beaten by her sister, Bentley's mother ran at Sarah but stopped when Sarah shouted to her about what her son had done.

Sometime later, the account of Bentley continued:

Sarah said that when the police came to take his brother's son Bentley that her husband was angry because when they came to take him off to jail they put handcuffs on him. They didn't tell him they were coming. They told the Council and the Council didn't tell him. 'The Council got him sneaking'. She said he wanted to put the shop gurdugurdu [sacred] but she stopped him, but she had better get back to be sure that he didn't. Sarah came back around 4:00 PM and said that her husband had put [cursed] the shop and office, 'really gurdugurdu, to a really ceremony place in his mother's country. He is really boss of that place, then after him Monroe 
and Walt. They could take it off, but only if he says yes. He wants it to stay like that for a week. Everybody is asking me to tell that old man to take it off, but I said, "No". I don't know where that old man is. He put the shop and left.' (Field notes, 1978)

In his anger, Sarah's husband put what today is referred to as a 'curse' on the shop and office, rendering them sacred and thus unusable for the vast majority of the population. Numbulwar had no permanent police presence at that time, so we must presume that Bentley's theft was reported to the council, which in turn notified the police on Groote Eylandt, who then came to Numbulwar to take Bentley off to court or to jail, an act that clearly outraged his father's brother. Bentley's act, along with teaching a young teen to steal, assuming he didn't know how to do so already, led to a near fight between Sarah and her sister, for parents may fight with others, even close relatives, to defend a child of any age (Burbank 1994, 75-78). It also inconvenienced the community when the shop and office were closed as these two venues provided services relied upon by many.

On none of my visits to Numbulwar has youth-created disruption been absent. In 1988, for example, a woman mentioned that:

The men did that business [ceremony] last night but still those young girls and young boys were sniffing [petrol] and calling out and crashing around, playing tape. We didn't sleep much. (Field notes, 1988)

Youth misbehaviour not only disturbs the adult community, it disturbs adolescents too. Here I am speaking with an 18-year-old about harassment and gossip that may have arisen from competition over a boyfriend:

Kinsey: [My life] it's now bad. Because people growling at me, makem me upset. And making me worry about, like worry inside, making me think about my father mob. If people like growling at me and make me upset, that's why. Or talk about you behind your back and you don't know, that make you upset and worry and skinny.

VKB: What's that behind the back talk?

Kinsey: Anything, like maybe talk about you for anything, or they jealous to you, you know, like girl. They talk about you for anything.

VKB: Other girls been talk about you? 
Kinsey: Yeh.

VKB: What for that behind the back talk make you think about your father?

Kinsey: Maybe they talk about me and make me upset and make my father and mother upset too. They gonna talk to them too ... They talking to that girl. Like explain with them not to teasing, 'Cause you might make a big problem, your mother and father might end up fighting', with my mother and father, and stab each other. They might stab each other, eh? (Burbank 2011, 84-85)

Kinsey was not only 'upset' by her peers' harsh words and gossip, she was also concerned about her parents, that they might be injured in a fight. The concerns of this insightful teen suggest the intensely negative feelings that parents may have, and the actions they might take, when the welfare of their children is threated by others. Youth behaviour clearly adds to the unpleasant stresses of daily life that are already considerable in remote communities like Numbulwar (e.g. Brady 1992; Brooks 2011; Senior and Chenhall 2008; Tonkinson 2011). Why then, outsiders might ask, don't these communities attempt to control them to a greater extent than they do at present?

\section{Sex, Drugs and on the Dole}

Recent research on the adolescent brain suggests that the early teenage years may be an especially vulnerable time for at least some young people. This, it is thought, may be due, in part, to developmental changes that take place in the limbic system, where, along with the anterior cingulate cortex, motivation may be said to originate (Tse 2013, 187). During adolescence, the limbic system is highly sensitised to reward and the presence of peers by increases in gonadal hormones, dopamine and dopamine receptors. This sensitivity may lend itself to the risk-taking so often seen in youth behaviour, especially in the presence of peers. The wellbeing of young people, then, may depend on a degree of external adult guidance and control (e.g. Casey 2015; Chein et al. 2011; Konner 2010).

A number of pre-industrial communities appear to have discovered this. According to Alice Schlegel and Herbert Barry (1991), who undertook a cross-cultural study of adolescence in 186 societies, this is a time when peer groups may, at least temporarily, hold greater sway over an individual 
than the family. However, adults in some settings may be those who 'determine the activities of these groups'; it is they, not youth, who 'make the demands, provide the resources and bestow the rewards' of peer group activity (75). Youth peer groups may be appropriated for communitywide projects whether of a military, religious, economic or social nature. In the latter domain, adolescents may be responsible for organising or contributing to events such as balls, festivals, rituals, weddings and funerals. They may also be recruited as 'agents of social control' (82), overseeing both the actions of their peers and of adults. These community roles and the presence of adults (135-37) may be vital to the wellbeing of a youth cohort as the peer group at this life stage can be a major socialising force. In certain circumstances, 'it can equal the family in the enforcement of behaviour and inculcation of values' (69).

The Aboriginal people of Numbulwar may have once controlled the behaviour of their young people too, through a prolonged process of religious indoctrination for males and early, often polygynous, marriage for females. Both these arrangements, however, were undermined by mission dictates and the laws and institutional arrangements of the encroaching polity. Little by way of control of young people appears to have taken their place (Burbank 1988, 33-41). It is, then, perhaps no accident that it is largely in the peer-directed peer groups of today that many of Numbulwar's youth engage in the behaviours that so concern the older generations: substance abuse, vandalism, theft and (relatively) unregulated sexuality. ${ }^{3}$

In Western settings, beyond the family, youth are guided and controlled to some extent by high schools. This arrangement, however, may only be effective if students believe that the activities they are directed to undertake will enable a desired future (see D'Andrade 1992; Steinmayr and Spinath 2009). And, as many a Western parent knows to their sorrow, there are many other, more powerful, organisations working against this purpose - the automobile, alcohol, tobacco, drug, entertainment, IT and fashion industries, to name just a few institutions in consumer society that usually appear indifferent to children's wellbeing.

3 On the basis of their cross-cultural study of adolescence, Schlegel and Barry (1991, 135-37) have suggested that delinquent behaviour may, in large part, be attributed to the absence of adult companionship. 
Some of Numbulwar's youths continue on to the later grades of high school. But it is unlikely that schooling holds the promise that is does for some Western youth. Here are the words of a teacher speaking in 2003:

We're trying to educate students to a high level and what this does is raise the level of frustration and here there is no pathway, no jobs, no one to hire our students. The community doesn't have a mine, a source of money, there is nothing here. No infrastructure. I don't see where the education is leading. These kids put all this effort into education and end up on $\mathrm{CDP}^{4}$ collecting trash. (Burbank 2011, 27)

The school is not an institution likely to control most of its students. It cannot teach the means of achieving a desired future, for who knows what that might be. Nor does initiation into the Law, the religious life of the Dreaming, have a sufficient hold on youths. As anthropologists have already noted, once the Law is challenged by other discourses, the controlling effects of initiation are weakened (see Hiatt 1985; Myers 1980; Sackett 1978; Tonkinson 1974). The Law at Numbulwar has certainly been challenged by years of mission proselytising and Western education. But, even if this were not the case, there are diminishing numbers of men to teach young boys. Too many, who once might have been their teachers, are dead, disabled or caught up in a prolonged adolescent phase of their own, so to speak, given their continuing abuse of alcohol and/or cannabis. Along with the enhanced sensitivity of the adolescent limbic system, we might see the problems of youth at Numbulwar as a mismatch between potentially controlling agents and the current environment. Neither the school nor the Law is suited for doing so in the context of this community.

\section{Exceptions: Positive Risk}

The adolescent brain may be characterised as one that is highly sensitive to environmental factors, particularly those of a social nature. Research-based accounts in cognitive psychology and neuroscience portray adolescents as acutely aware of, and affected by, sociocultural cues, including those that come from explicit teaching, social evaluation and social rejection, especially by peers (e.g. Worthman and Trang 2018, 32; Crone and Dahl

4 ' $\mathrm{CD}[\mathrm{E}] \mathrm{P}$ ' refers to CDEP, a Commonwealth work program designed for Indigenous communities (Sanders 2005). In the 2000s, the acronym was pronounced with a silent E. 
2012, 640; Blakemore and Mills 2014, 187-89). The combination of this sociocultural sensitivity and a propensity for risk-taking can be a positive, if not essential, development in the right kind of environment insofar as it can enhance learning (Blakemore and Mills 2014, 200). And, as we might imagine, as brain development and related behaviours are not necessarily uniform across all young people, and as these differences appear to be caused, in large part, by sociocultural factors, among which are family and school environments, positive sociocultural experience may be associated with positive youth behaviour. We might also keep in mind, as some researchers have suggested, that: 'Individual differences in neurobiology can determine how sensitive an adolescent is to their social context indicating that identical social environments might affect different individuals in different ways' (Foulkes and Blakemore 2018, n.p.).

Sawyer appears to have been one of those adolescents whose brain was put to good use. Petrol sniffing was present in his youth, but he was not one of the sniffers. And there are, of course, young people at Numbulwar today who do not vandalise or steal, take to petrol, alcohol and drugs, or conceive children, sometimes with incorrect partners according to local marriage rules, at an early and unhealthy age. We may assume positive experiences for some of Sawyer's 'family', that is the large extended 'family' of 'close' relations, and, perhaps, of the education they receive from the school's teachers and/or the community's ritual leaders. We may also assume a kind of neuropsychological development that assists a positive view of the social environment whatever it might be.

Sawyer would have been born around the time that Numbulwar was first established as Rose River Mission in 1952, but he did not live there until he was nine or 10 years of age. His first years of life were spent in the bush around cattle stations like Tanumbirini and on the settlements of Borroloola and Ngukurr. Here is an excerpt from the story of his early years:

I never went to school until I was about this high [about a metre tall]. I went back to Ngukurr, only place I went to school. Missionary said, 'You have to start school from the very start, we have to move you back to kindergarten. That's the Law ... Older kids from the school used to tease me, big boys who said, 'What's a big boy doing in the kindergarten?' Every day they came to tease me. That made me think very hard. This is my voice, 'I can't stop teasing. I gotta work hard as I can to learn education, learn hard to write, learn hard to read, all, all this, they do in school'. Promise 
I made to myself. So from then I did just that. I learned how to read, write, I learned ABC. I worked very hard at sums ... I came to Numbulwar. I went to school ... But I was still studying very hard, not only white man side of things. I was also sitting down listening to elder people, stories from our parents, telling stories around the fire. I didn't get involved in any ceremony yet, only corroboree and stories why they sing corroboree. Then I been learn how to survive out bush, what kind of spear you need to catch fish. If you need to cut meat without a knife, you need stone axe. All the studying our culture way of doing things. Mostly learning how to survive when in the bush. They taught me all that. When I went into first circumcision ceremony, I was about 10 years of age. And after that I been study very hard why they do circumcision. We don't make it up, it's been there for centuries. Then I been learning big heavy laws for men when I was 12 and 13 and I been go though the other two big ceremonies. But one thing I've learned since I was 10 or small boy, ${ }^{5}$ I been learn about respect. (Sawyer, 20 November 2003)

Some people, of course, take to Western education more readily than others, perhaps due to abilities that make learning the three Rs more satisfying (Steinmayr and Spinath 2009). In Sawyer's case, an additional incentive might be found in his equation of success at school with respect from his peers. But why would his peers have chosen school level as a reason for teasing? This act suggests that at least some value was placed on Western education by these young students. For as long as I've been acquainted with Numbulwar, school attendance has always been a problem. And I suspect this was the same at Ngukurr at that time. School does not appear high on the list of many children's priorities, nor, I suspect, on that of their families. It is, however, a whitefella thing and whitefella things are admired (see also Musharbash 2008). Sawyer, for example, thinks highly of refrigeration:

There are a lot of good things munanga [whitefella] way. You can look at keeping food for a number of months. Flour, bread, meat can be put in the fridge to keep for two or three months. Good way of living, munanga way. (Sawyer, 2004)

5 Calculating age chronologically is a relatively new practice in parts of Aboriginal Australia and numbers given may only provide a rough estimate (see Burbank 1988, 10-11). 
At least some Aboriginal people, I suggest, see an association between literacy and whitefella wealth. In 1978, for example, several adults saw proposal writing as the means of acquiring Land Rovers and other desired goods. Whether we are speaking of the clothes, vehicles and houses of the mission period or the mobile phones, computers, iPods and CD players of more recent times, school may be a symbol of whitefella power, a power that might be achieved by anyone who can learn what it has to teach. However, this belief might have been more likely in the early days of Numbulwar's settlement when firsthand experience may not have complicated ideas of how whitefella power was acquired.

Yet, Sawyer appears to have found meaning in more than just Western learning. The Law also holds value for him. He equates knowledge of his culture with both respect and survival. We should ask why this might be so in a setting in which the Law's value is undermined by Christianity and other Western discourses. Here I would suggest that an early and intensely emotional experience in which Aboriginal beliefs were central, motivated, at least in part, his dedication to the Law:

When my mother passed away we were at Rosy Creek ... There was a stock camp there. My mother and father travelled all the way from Borroloola, going to Rosy Creek ... but my mother got sick. My father didn't want her to stay in hospital in Borroloola. She was really sick. She passed away, we were in the middle of nowhere. No telegraph, no telephone to ring up my mother's sister to come out. My mother's sister was staying at Tanumbirini, they used to work there, stock hand, to catch more bullocky [cattle], we call them. She stayed there, my mother's sister, Sarrri. When my mother died, nothing to get in touch to ask her to pick me up. We had no car, no plane ... I had a little brother too who was already born but he was too small, he could only eat breast milk. The other ladies there had no breast milk and maybe they were too scared to ask for powdered milk or goat's milk. ${ }^{6}$ That night my brother passed away too. So I had two deaths. And when my mother passed away, this is the incredible thing that she did. She said, 'I better go to my sister'. She went to Tanumbirini. This was the last thing she did because she really loved and cared for me and my younger brother. She knew those old ladies there couldn't help. So she went to Tanumbirini and when she went there and old Sarri was sleeping. And she came out in the room where they

6 In another telling of this account, Sawyer mentions that the old ladies thought they might be shot if they approached a whitefella. 
were camping and said to Sarri, 'You don't have to look at me, this is me, your sister. You gotta leave tomorrow early. If you can't leave early tomorrow both of my sons will pass away. You have to go straight to Rosy Creek cause that's where you'll find them.' She said to her, 'Go ask the manager to give you spare horse to go'. And when old Sarri listened to her she cried because she knew her sister died. Early next morning she went to the manager and she said, 'I need you to give me some horse, I gotta save two boys, they might end up dying'. I was a lot bigger than my younger brother. She packed up the horse and left, took three days and three nights to reach us. She travelled, no rest, to reach us. If I had a map here, I could show you how far she travelled. When she got there my younger brother passed away. She was a day late. I was still alive, still running. I still ran to meet her when she came. It's an incredible story. At least she save my life. If she had come a day earlier she would have saved my brother. I would have a brother with me. At least she saved me. (Sawyer, 20 November 2003)

I do not know when and how Sawyer learnt the story of his rescue, a distinctively Aboriginal discourse. It may have been told just once or repeated throughout his childhood and adolescence. Or it may have been one he remembered, at least in part, or created and told himself. Whatever may be the case, it appears to be an important part of his autobiography. The events it details are the source of Sawyer's salvation, his survival in spite of an absence of Western forms of communication or Western assistance. Hence, I think, his willingness to take the Law seriously, to see his 'culture ways of doing things' as a means of staying alive and thus worth learning.

In his youth, Sawyer could be described as a risk taker, but one who appears to have largely engaged in its positive forms if we can agree that he was taking risks in pursuing both Western and Indigenous knowledge. It is members of a boy's 'family' who decide that he is ready to be circumcised and begin his engagement with the series of rituals that are a male prerogative. However, a child's behaviour may be such that a family daren't approve of his participation, for if a new initiate does not follow the Law, punishment may be severe. As the following conversation we had on youth delinquency reveals, Sawyer was well aware of the dangers associated with ritual participation:

All the stages you go through after circumcision, you will be learning. Small boys are told they can't do anything wrong. And when they go to second stage, really really strong, they are told again. They are out there two, three months, taught it, have to be 
reminded every day, 'This is the Law, can't break Law'. And once come out of the thing they are warned, 'We will be keeping an eye on you. We. You do anything wrong, even if you argue with parents, you will be punished'. (Sawyer, 4 August 2004)

Western education may have also involved some risk from Sawyer's perspective:

So I thought in my young days that I was an electrician. That's what I really loved, that was the choice I had when I was in school. So I did go into Darwin to do electrician course. I been there twelve months, one year, and I received the certificate. (Sawyer, 20 November 2003)

Although Sawyer doesn't say so, he, like youths from Numbulwar who find schooling in Darwin difficult, may have been homesick and lonely during that year. I once asked eight women if they would like to live in a place like Darwin and all replied in the negative, six of them using the words 'homesick or boring"7 in their replies. We can imagine that young people might find it even more so. One adolescent girl even saw the city as dangerous:

Something night happen [in the city]. Car accident or someone gonna stab me with the knife. It's dangerous. If you go and see the Long Grass People [who go to Darwin to drink or take drugs], they give you shit for money and they stab you with the knife. They got the knife in the pocket. You gotta be careful to yourself. (Kinsey quoted in Burbank 2011, 167)

Sawyer, though, was prepared to return to Darwin after his first year there, however lonely and homesick he might have felt:

I was top man on the exam so the teacher said, 'I think you need more training'. So I went [back to] Darwin for [another course] ... Then after that they came to tell me there is no more money to fly you into Darwin. ${ }^{8}$ That was a waste. I had to come back to

7 The word 'boring' as it is used at Numbulwar has a social component not usually found in its whitefella usage. For example: 'It's boring, nobody walking around, it's too dead' (in Burbank 2011, 167; see also Musharbash 2007).

8 In 2004, when retelling this part of the story of his education, Sawyer said:

Then I received the certificate ... I came back here but before I was going to Darwin, I had bad news, bad story, because government changed. The new government put up different things, the department looking after us, I think it was Welfare, had a different policy. Not enough money to take me back to do the apprenticeship. That was a big loss. But I didn't give up. I got a job as assistant electrician. (Sawyer, 1 September 2004) 
this community and started work here as electrician. And from that time, I been picking up and learning as much as I could learn. I've worked in the work shop. I was there when you came here, first time [1977-78], I remember. (Sawyer, 20 November 2003)

Sawyer might be regarded by some as a near orphan, his mother dead by his early years, his father often absent, at least during his childhood. He may have also seen himself in this way:

I never started school, preschool. In those days I was living out bush, living with one family, not my family, this family that looked after me. I was looked after by a lot of family really, when we lived out bush. (Sawyer, 20 November 2003)

I think that here Sawyer is attempting to communicate the distinction between his biological parents and more distant relatives to an outsider, whom he cannot assume is familiar with the way in which 'family' is calculated. But it is notable that he was making this kind of distinction, one that, as I have demonstrated elsewhere, is made at Numbulwar (Burbank 2018). He was, however, being cared for by 'family'; therefore, others would not have considered him to be an orphan, a wangulu, in the local scheme of things (Burbank 2011, 151-52). Eventually, he was 'rescue[d]' by people who appear to have been closer kin:

I went to school at Ngukurr. My father was there. [Two other clansmen and] Old Sarri came up and rescue me. I owe her a lot. I owe her my whole life ... That's why I've lived at Ngukurr, four, five years. I been at school. But inside my heart I miss my mother and my brother and sisters. I had a space inside my heart; really want to be with them. I got lucky. My father was taken [away for prolonged medical treatment]. Umbakumba people came with the work boat, brought supplies from Groote to Numbulwar and Roper and they seen me there at Ngukurr. I was at the river for a swim. Maybe I was on the swing. 'Hey, is that Sawyer?' ... They recognized me because I been to Groote, Umbakumba, when I was a kid. 'You can't stay here. Your father [away getting treatment], you can't stay here. Too many mulunguwa [murderers, usually from outside a community] here. We gotta take you back' ... I guess when [a woman] got off here [at Numbulwar from the transport] she been start yelling top of her voice, calling [to one of Sawyer's kinsmen]. 'Sawyer here'. [Two of his clansmen] came out running and Old Sarri heard too ... and as soon as I saw them I was really happy, I had a mother. That's the one thing I was missing in my life. She's my mother's elder sister. So that was my 
destiny and I lived here ever since. When my father came back from [his medical treatment] he wanted me to meet the plane. I went to airstrip on the tractor. He said to me, 'I'm not going to take you away'. He went to Roper, worked and came back here. (Sawyer, 8 September 2004)

What most strikes me about this part of Sawyer's narrative is how it is presented in accord with the story of his mother's death and attempt to save her sons. In neither account does he focus on any kind of neglect; rather, he paints his kin as his saviours and emphasises, in the former story, his mother's love for him and, in the latter, his appreciation of his 'mother' Sarri. This may be a form of impression management, of course, but I think it more likely reflects how Sawyer really felt, or wanted to feel. That is, I propose that Sawyer's view of his life, in particular of the family environment of his formative years, is as much a consequence of his social need, intelligence and persistence as a reflection of what it really was. Sawyer has subsequently led a life unlike many others at Numbulwar with the benefits of two seemingly incompatible forms of education. This, I think, is largely due to the idiosyncrasies of his life history, to the particularities of his social environment, and of his psychobiological make-up, which is, of course, a product of his social environment as well as of his genotype (e.g. Konner 2010, 159-201; LeDoux 2002, 65-96).

\section{Conclusion}

There is more to say about the guidance and control of youth in remote Aboriginal communities. This conversation might include the necessary attributes of adults for their presence in young peoples' lives to be a beneficial one, the effect of family culture on youth behaviour and the complications of both these factors in remote Aboriginal Australia. What I want to emphasise here, however, is the complexity of individual human lives and life chances. Other children may have intense Aboriginally redolent experiences and so be protected from outside challenges to the Law. Other children at Numbulwar may have Sawyer's kind of intelligence and find delight in reading and what they learn at school. They may have his interest and drive and thus be susceptible to the healthy control that these two forms of education have a potential to exert. They may have the kinds of family relationships (or see their family relationships to be of the kind) that encourage them to follow their dreams and take positive risks. If we are to be of any help to Aboriginal communities in their attempts to 
enable the healthful development of their youths, it is for anthropologists to abstract the components of idiosyncratic life histories that may be replicated in other youths' lives, and to understand their relations with aspects of the encompassing sociocultural environment.

\section{References}

Austin-Broos, D. 2011. A Different Inequality: The Politics of Debate about Remote Aboriginal Australia. Crows Nest, NSW: Allen \& Unwin.

Biernoff, D. 1979. 'Traditional and Contemporary Structures and Settlement in Eastern Arnhem Land with Particular Reference to the Nunggubuyu'. In A Black Reality: Aboriginal Camps and Housing in Remote Australia, edited by M. Heppell, 153-79. Canberra: Australian Institute of Aboriginal Studies.

Blakemore, S-J. and K. Mills. 2014. 'Is Adolescence a Sensitive Period for Sociocultural Processing'. Annual Review of Psychology 65: 187-207. doi.org/ 10.1146/annurev-psych-010213-115202.

Brady, M. 1992. Heavy Metal: The Social Meaning of Petrol Sniffing in Australia. Canberra: Aboriginal Studies Press.

Brooks, D. 2011. 'Organization within Disorder: The Present and Future of Young People in the Ngaanyatjarra Lands'. In Growing Up in Central Australia: New Anthropological Studies of Aboriginal Childhood and Adolescence, edited by U. Eickelkamp, 183-213. Oxford: Berghahn Books.

Burbank, V. 1988. Aboriginal Adolescence: Maidenhood in an Australian Community. New Brunswick, NJ: Rutgers University Press.

Burbank, V. 1994. Fighting Women: Anger and Aggression in Aboriginal Australia. Berkeley: University of California Press.

Burbank, V. 2011. An Ethnography of Stress: The Social Determinants of Health in Aboriginal Australia. New York: Palgrave Macmillan. doi.org/10.1057/ 9780230117228 .

Burbank, V. 2018. 'Of Mothers, Adoption and Orphans: The Significance of Relatedness in a Remote Aboriginal Community'. In Focality and Extension in Kinship: Essays in Memory of Harold W. Scheffler, edited by W. Shapiro, 203-24. Canberra: ANU Press. doi.org/10.22459/FEK.04.2018.06.

Casey, B. 2015. 'Beyond Simple Models of Self-Control to Circuit-Based Accounts of Adolescent Behaviour'. Annual Review of Psychology 66: 295-319. doi.org/ 10.1146/annurev-psych-010814-015156. 
Chein, J., A. Duston, L. O’Brien, K. Uckert and L. Steinberg. 2011. 'Peers Increase Adolescent Risk Taking by Enhancing Activity in the Brain's Reward Circuity'. Developmental Science 14 (2): F1-F10. doi.org/10.1111/j.1467-7687.2010. 01035.x.

Cole, K. 1982. A History of Numbulwar. Bendigo, Vic.: Keith Cole Publication.

Crone, E. and R. Dahl. 2012. 'Understanding Adolescence as a Period of SocialAffective Engagement and Goal Flexibility'. Nature Reviews Neuroscience 13: 636-50. doi.org/10.1038/nrn3313.

D’Andrade, R. 1992. 'Schemas and Motivation'. In Human Motives and Cultural Models, edited by R. D’Andrade and C. Strauss, 23-44. Cambridge: Cambridge University Press. doi.org/10.1017/CBO9781139166515.003.

Foulkes, L. and S-J. Blakemore. 2018. 'Studying Individual Differences in Human Adolescent Brain Development'. Nature Neuroscience 21: 315-23. doi.org/10.1038/s41593-018-0078-4.

Heath, J. 1980. Nunggubuyu Myths and Ethnographic Texts. Canberra: Australian Institute of Aboriginal Studies.

Hiatt, L. 1985. 'Maidens, Males, and Marx: Some Contrasts in the Work of Frederick Rose and Claude Meillassoux'. Oceania 56:34-46. doi.org/10.1002/ j.1834-4461.1985.tb02106.x.

Konner, M. 2010. The Evolution of Childhood: Relationships, Emotion, Mind. Cambridge, MA: Harvard University Press.

LeDoux, J. 2002. Synaptic Self: How Our Brains Become Who We Are. New York: Viking.

Musharbash, Y. 2007. 'Boredom, Time and Modernity: An Example from Aboriginal Australia'. American Anthropologist 109 (2): 307-17. doi.org/ 10.1525/aa.2007.109.2.307.

Musharbash, Y. 2008. Yuendumu Everyday: Contemporary Life in Remote Aboriginal Australia. Canberra: Aboriginal Studies Press.

Myers. F. 1980. 'The Cultural Basis of Politics in Pintupi Life'. Mankind 12: 197-214. doi.org/10.1111/j.1835-9310.1980.tb01192.x.

Rowley, C. 1977. 'White Settlement and Interaction'. In The Australian Encyclopaedia, 3rd ed., 52-61. Sydney: Grolier Society of Australia.

Rowse, T. 2017. Indigenous and Other Australians Since 1901. Sydney: UNSW Press. 
Sackett, L. 1978. 'Punishment as Ritual: Man-Making among Western Desert Aborigines'. Oceania 49: 110-27. doi.org/10.1002/j.1834-4461.1978. tb01382.x.

Sanders, W. 2005. 'CDEP and ATSIC as Bold Experiments in Governing Differently: But Where to Now?' In Culture, Economy and Governance in Aboriginal Australia: Proceeding of a Workshop of the Academy of the Social Sciences in Australia Held at the University of Sydney 30 November - 1 December 2004, edited by D. Austin-Broos and G. Macdonald, 203-12. Sydney: Sydney University Press.

Schlegel, A. and H. Barry. 1991. Adolescence: An Anthropological Inquiry. New York: Free Press.

Senior, K. and R. Chenhall. 2008. 'Lukambat Marawana: A Changing Pattern of Drug Use by Youth in a Remote Aboriginal Community'. Australian Journal of Rural Health 16: 75-79. doi.org/10.1111/j.1440-1584.2008.00956.x.

Shapiro, W. 1981. Miwuyt Marriage: The Cultural Anthropology of Affinity in Northeast Arnhem Land. Philadelphia: Institute for the Study of Human Issues.

Steinmayr, R. and B. Spinath. 2009. 'The Importance of Motivation as a Predictor of School Achievement'. Learning and Individual Differences 19: 80-90. doi.org/10.1016/j.lindif.2008.05.004.

Tonkinson, M. 2011. 'Being Mardu: Change and Challenge for Some Western Desert Young People Today'. In Growing Up in Central Australia: New Anthropological Studies of Aboriginal Childhood and Adolescence, edited by U. Eickelkam, 213-38. Oxford: Berghahn Books.

Tonkinson, R. 1974. The Jigalong Mob: Aboriginal Victors of the Desert Crusade. Menlo Park, CA: Cummings Publishing Company.

Tse, P. U. 2013. The Neural Basis of Free Will: Criterial Causation. Cambridge, MA: MIT Press. doi.org/10.7551/mitpress/9780262019101.001.0001.

Worthman, C. and K. Trang. 2018. 'Dynamics of Body Time, Social Time and Life History at Adolescence'. Nature 554: 451-57. doi.org/10.1038/nature25750. 
This text is taken from Indigenous Australian Youth Futures: Living the Social Determinants of Health, edited by Kate Senior, Richard Chenhall and Victoria Burbank, published 2021 by ANU Press, The Australian National University, Canberra, Australia.

doi.org/10.22459/IAYF.2021.10 